\title{
Dampak Pernikahan Dini Di Desa Keruak Kecamatan Keruak Kabupaten Lombok Timur
}

\author{
${ }^{1}$ Dewi Puspita Ningsih, ${ }^{\mathbf{2} D i d i n}$ Septa Rahmadi \\ Program Studi Pendidikan Sosiologi, Universitas Nahdlatul Ulama NTB \\ Email: dewining66@gmail.com \\ Phone: 085333046068
}

\begin{abstract}
Abstrak
Penelitian ini bertujuan untuk: 1) Mengetahui dampak pernikahan dini yang terjadi pada masyarakat Desa Keruak. 2) Cara yang diterapkan dalam menekan angka pernikahan dini di Desa Keruak. Penelitian ini merupakan penelitian kualitatif deskriftif dengan pendekatan naturalistik. Penelitian dilakukan selama 1 tahun. Subjek penelitian adalah masyarakat kaum muda Desa Keruak pelaku pernikahan dini. Penentuan informan dengan carasnowball sampling. Teknik pengumpulan data adalah observasi, wawancara, dan dokumentasi. Analisis data secara deskriptif, dengan: 1) reduksi data, 2) abstraksi data, dan 3) penarikan kesimpulan. Hasil penelitian menunjukkan. 1) Dampak yang ditimbulkan akibat dari pernikahan dini yang berlangsung di Desa Keruak; 2) Sosialisasi dan pendekatan merupakan cara yang dilakukan untuk menekan angka pernikahan dini.
\end{abstract}

Kata kunci: Dampak, Pernikahan Dini

\section{Abstract}

This study aims to: 1) Know the impact of early marriage that happened to the people of Keruak Village. 2) Ways applied in suppressing the rate of early marriage in Keruak Village. This research is descriptive qualitative research with a naturalistic approach. The study was conducted for 1 year. The research subjects were the young people of Keruak Village. Determination of informants by snowball sampling. Data collection techniques are observation, interviews, and documentation. Descriptive data analysis, with: 1) data reduction, 2) data abstraction, and 3) conclusion. The results of the study show. 1) Impact caused by early marriages that took place in Keruak Village; 2) Dissemination and approach is a way to reduce the number of early marriages.

Keywords: Impact, Early Marriage

\section{PENDAHULUAN}

Pernikahan bagi manusia merupakan suatu cara yang dipilih oleh Allah sebagai jalan bagi meraka untuk mengembnagkan keturunan, beranak, melestarikan kehidupanya, setelah masing-masing pasangan dari mereka (laki laki dan perempuan) sudah siap melakukan perannya yang positif dalam mewujudkan tujuan pernikahan yang sah.

Syarat pernikahan yaitu menghendaki kemampuan , materi, usia, kematangan psikologis, fisik dan mental untuk melangsungkan pernikahan, karena kemampuan, materi,usia, kematangan Jurnal Ilmiah Mandala Education psikologis dan mental itulah nantinya yang akan menentukankelangsungan atau umur dari sebuah pernikahan, agar dapat mewujudkan tujuan pernikahan secara baik tanpa berakhir pada perceraian dan mendapat keturunan yang baik dan sehat, sehingga harus dicegah adanya pernikahan antara calon suami atau istri yang masih dibawah umur

Dalam Undang-Undang Perkawinan No. 1 Tahun1974 menentukan batas umur untuk kawin baik pria maupun wanita, ialah 19 tahun bagi pria dan 16 tahun bagi wanita, karena umur merupakan salah satu penentu hal yang urgen. Umur dalam hal ini menyangkut umur kedua 
belah pihak yakni laki-laki dengan perempuannya sudah pada standar usiapernikahan atau umur kedua belah pihak masih tergolong relatif muda atau disebut pernikahan usia muda atau usia dini. Pengertian pernikahan dini adalah pernikahan yang dilakukan oleh salah satu pasangan yang memiliki usia di bawah umur yang biasanya di bawah 17 tahun. Baik pria atau wanita jika belum cukup umur (17 Tahun) jika melangsungkan pernikahan dapat dikatakan sebagai pernikahan usia dini. Di Indonesia sendiri pernikahan belum cukup umur ini marak terjadi, tidak hanya di desa melainkan juga di kota. Menurut BKKBN sendiri pengertian pernikahan dini ialah pernikahan di bawah umur yang disebabkan oeh factor social, pendidikan, ekonomi, budaya, factor orang tua, factor diri sendiri dan tempat tinggal

Seringkali pernikahanusia dini ini di dalam masyarakat mendapat pertentangan, karena tidak bisa dipungkiri bahwa fenomena ini bisa mengakibatkan terjadinya sebuah masalah dalam pernikahan, baik itu masalah yang datang dari keluarga kecil itu sendiri atapun masalah yang datang dari luar kkeluarga.

Pernikahan dini juga dinilai mempunyai risiko serius yaitu dari permasalah kemiskinan, kesehatan bayi hingga rentan mengalami kekerasan dalam rumah tangga (KDRT) khususnya berdampak pada perempuan. Saat ini Mahkamah Konstitusi (MK) tengah mengkaji usia pernikahan yang pantas bagi perempuan, apakah masih sesuai UU Pernikahan atau perlu diubah.

Berkaitan dengan hilangnya hak kesehatan, seorang anak yang menikah di usia dini memiliki risiko kematian saat melahirkan yang lebih tinggi dibandingkan dengan wanita yang sudah cukup umur. Risiko ini bisa mencapai lima kali lipatnya. Selanjutnya, seorang anak perempuan yang menikah akan mengalami sejumlah persoalan psikologis seperti cemas, depresi, bahkan keinginan untuk bunuh diri. Di usia yang masih muda, anak-anak ini belum memiliki status dan kekuasaan di dalam masyarakat. Mereka masih terkungkung untuk mengontrol diri sendiri.Terakhir, pengetahuan seksualitas yang masih rendah meningkatkan risiko terkena penyakit infeksi menular seperti HIV.

Tingginya insiden pernikahan anak di Indonesia khususnya wilayah pedesaan pada akhirnya justru lebih banyak memunculkan implikasi yang negatif seperti kemiskinan. Bagi rumah tangga miskin, anak perempuan dianggap sebagai beban ekonomi dan pernikahan dianggap sebagai solusi karena lazimnya setelah menikah, kebutuhan pangan, sandang dan papan menjadi tanggung jawab suami. Namun, kondisi ekonomi anak dalam keluarga barunya banyak yang tidak menjadi lebih baik atau tidak sesuai dengan harapan daripada saat sebelum menikah. Mereka tetap kesulitan memenuhi kebutuhan pangan, dan justru menambah beban bagi orangtuanya. Sumber penghasilan rendah karena minimnya pendidikan, bertambahnya jumlah anggota keluarga dengan kehadiran anak pada akhirnya memberi tekanan ekonomi yang semakin besar pada rumah tangga. Kesulitan ekonomi inilah yang dapat memicu terjadinya pertengakaran yang berujung perceraian.

Kondisi itu justru menciptakan lingkaran kemiskinan karena banyak pasangan laki-laki yang juga terlalu dini usianya untuk menikah. Belum ada kesiapan secara mental, ekonomi, bahkan sosial untuk menikah. Selain terkait dengan persoalan kemiskinan, pernikahan dini juga memunculkan masalah kesehatan. Banyak penelitian menunjukkan, risiko kehamilan maupun persalinan pada anak begitu tinggi. State of World Population 2013 yang diluncurkan oleh Lembaga Dana Kependudukan PBB (UNFPA) menyebutkan, 70 ribu kematian remaja terjadi setiap tahuan akibat komplikasi yang dialami semasa kehamilan maupun persalinan. Angka risiko kematian bayi lebih besar, bayi lahir dalam keadaan prematur, kurang gizi, dan anak berisiko terkena hambatan pertumbuhan atau stunting. Lebih lagi, pernikahan anak juga berkolerasi erat dengan persoalan kekerasan dalam rumah tangga (KDRT), tingginya angka putus sekolah, bahkan 
risiko tertular penyakit sepert HIV/AID, dan Obstetrict Fistula.

Berbagai sumber yang didapatkan di lapangan, diketahui bahwa memang tingkat perceraian di Pulau Lombok cukup tinggi, sehingga banyak orang menyebut pulau Lombok memiliki tradisi unik yaitu tradisi kawin-cerai. Tradisi kawin cerai banyak terjadi pada kalangan usia muda. Fakta pernikahan dikalangan usia muda dan terjadinya perceraian merupakan keadaan yang tidak bisa dikesampingkan. Minimnya pendidikan dan keadaan ekonomi turut andil dalam memicu terjadinya perceraian usia muda

Banyak fenomena pernikahan pada usia muda yang terjadi sekarang ini yang bisa saja memicu terjadinya perceraian, dan bisa saja terjadi pada sebagian masyarakat yang melangsungkan pernikahan usia muda yang belum memiliki kesiapan mental atau psikis untuk menghadapi pernikahan. Kekacauan keluarga ini biasanya menyebabkan terputusnya suatu system peranan dalam keluarga karena salah satu bagian dari keluarga tersebut (istri misalnya) merasa tidak nyaman terhadap keluarga yang sedang dibinanya tersebut, sehingga salah satu bagian dari keluarga tersebut memutuskan untuk memutuskan system peranannya di dalam keluarga. Kekacauan keluarga dapat ditafsirkan sebagai pecahnya suatu unit keluarga, terputusnya atau retaknya struktur peranan social yang disebabkan oleh gagalnya salah satu atau beberapa anggota di dalam keluarga menjalankan kewajiban perannya di dalam keluarga. Hasil akhirnya yakni terjadinya kasus perceraian yang cukup tinggi dalam masyarakat.Baik itu pada masyarakat perkotaan ataupun pada masyarakat pedesan, yang diakibatkan oleh banyak faktor, baik itu dari dalam keluarga ataupun dari luar keluarga itu sendiri.

Berdasarkan realita yang terjadi pada masyaraka Desa Keruak, peneliti melihat semakin marak saja terjadi pernikahan usia muda yang dilanjutkan dengan perceraian, pernikahan disini seakan mudah saja dilakukan baik dari orang yang sudah mampu ataupun belum mampu menjalankan rumah tangga yang hakiki asalkan sudah ada niat dan berani untuk bertanggungjawab maka pernikahan bisa terlaksana walaupaun banyak yang pada akhirnya harus meninggalkan bangku pendidikan yang sedang meraka tempuh.

Dari hal ini tentu saja banyak dampak yang akan muncul jika praktik pernikahan dini ini terus dilakukan. Sehingga ini suatu hal serius yang harus ditangani bersama, perlu adanya peran kerjasama antara orangtua dengan pihakpihak yang terkait agar praktik pernikahan dini ini bisa ditanggulangi, sehingga bisa menyelamatkan banyak masa depan dari anakanak di Desa Keruak.

\section{Metode Penelitian}

Penelitian ini menggunakan penelitian kualitatif deskriptif dengan pendekatan naturalistik. Penelitian kualitatif deskriptif, ditujukan untuk mendeskripsikan atau menggambarkan fenomena-fenomena yang ada, baik fenomena yang bersifat alamiah ataupun rekayasa manusia.

\section{Tempat dan Waktu Penelitian}

Penelitian ini berlokasi di wilayah Desa Keruak Kabupaten Lombok Timur. Adapun waktu penelitian ini dilaksanakan kurang lebih 1 Tahun

\section{Subjek dan Objek Penelitian}

Subjek penelitian ini adalah masyarakat/kaum muda yang sebagai pelaku pernikahan dini yang ada di lokasi penelitian. Penentuan subjek dilakukan dengan cara snowball sampling. Informan ditentukan atas pertimbangan tujuan penelitian dengan kriteria jaringan informan atau informan yang sesuai dengan yang peneliti butuhkan dan dikenal baik juga oleh informan yang sebelumnya. Adapun objek dalam penelitian ini adalah Dampak Pernikahan Dini Pada Masyarakat Desa Keruak

Teknik dan Instrumen Pengumpulan Data

Instrumen dalam penelitian ini adalah peneliti sendiri (human instrument) yang 
berfungsi menetapkan fokus penelitian, memilih informan sebagai sumber data, melakukan pengumpulan data, menilai kualitas data, analisis data, menafsirkan data dan membuat kesimpulan atas temuannya. Teknik dan instrumen pengumpulan data meliputi peroleh data teknik observasi, wawancawa secara mendalam, dan dilengkapi dengan dokumentasi. Teknik observasi digunakan untuk mengumpulkan informasi data yang primer sesuai dengan kebutuhkan penelitian. Dalam teknik observasi tersebut, peneliti tidak terlibat langsung dengan subjek penelitian

Teknik wawancara adalah salah satu teknik untuk mendapatkan informasi secara langsung melalui informan sebagai narasumber. Teknik wawancara tersebut digunakan oleh peneliti untuk memperoleh keteranganketerangan yang valid. Bentuk teknik wawancara yang digunakan bersifat terbuka (open ended). Pelaksanaan wawancara tidak dilakukan secara terjadwal, wawancara dilakukan secara fleksibel tergantung dari kesiapan responden.

Dokumentasi penelitian ini berkaitan dengan data yang bersifat dokumentatif. Data dari hasil teknik dokumentasi ini diperoleh dari dokumen-dokumen yang berupa: catatan pribadi, buku-buku, dan jurnal.

\section{Teknik Analisis Data}

Teknik analis data yang diperoleh di lapangan dianalisis menggunakan analisis deskriptif kualitatif. Penelitian ini mengajukan teknik analisis kualitatif untuk proses analisis data dengan menggunakan tahapan-tahapan berikut, diantaranya:

\section{Reduksi Data}

Reduksi data merupakan suatu bentuk analisis yang menajamkan, menggolongkan, dan diartikan sebagai proses, pemilihan, pemusatan perhatian pada penyederhanaan, dari catatancatatan tertulis di lapangan (Miles dan Huberman, 1992: 16).

\section{Abstraksi Data}

Jurnal Ilmiah Mandala Education
Abstraksi, yaitu membuat ringkasan inti, proses dan persyaratan yang berasal dari responden tetap dijaga. Pada langkah ini peneliti berusaha menyusun data yang relevan, sehingga menjadi informasi yang dapat disimpulkan dan memiliki makna tertentu dengan cara membuat hubungan antar variable atau fenomena.

\section{Penarikan Kesimpulan}

Tahap ini adalah tahap paling akhir dalam penelitian ini. Penarikan kesimpulan adalah proses peneliti mencari makna dari datadata yang diperoleh sehingga mampu memunculkan hasil akhir dari pengkajian dan reduksi data yang telah dilakukan. Pengambilan kesimpulan berupaya menemukan hasil akhir dari suatu penelitian.

\section{Pembahasan}

Pada dasarnya pernikahan usia muda terjadi oleh orang-orang yang usianya belum mencapai apa yang dimaksud Undang-Undang Perkawinan No.1 Tahun 1974 yaitu pria sudah mencapai umur 19 tahun dan wanita berusia 16 tahun. Alasan pernikahan dini tentu harus dipikirkan, di mana tanggungjawab suami istri untuk memikul kewajiban yang luhur untuk menjalankan rumah tangga menjadi dasar dari susunan masyarakat. Suami adalah kepala rumah tangga dan istri adalah sebagai ibu rumah tangga yang akan mengurus rumah tangga itu sebaik-sebaiknya, oleh sebab itu pernikahan hendaklah dilakukan oleh orang yang usianya sudah matang sehingga bisa menjalankan rumah tangga itu dengan sebaik-baiknya. Walaupun undang-undang terbaru UU No.16 tahun 2019 tentang perubahan atas UU No. 1 tahun 1974 telah disahkan, dimana batas usia menikah lakilaki dan perempuan 19 tahun, rupanya ini tak kunjung jua bisa menekan angka pernikahn dini di desa Keruak.

Tingginya angka pernikahan di desa Keruak menjadi polemik dalam dunia pendidikan, bahwasanya rata-rata yang menikah adalah anak-anak yang sedang menempuh bangku pendidikan pada tingkat SMP dan SMA. Ada banyak alasan anak-anak ini memilih menikah daripada melanjutkan pendidikannya, 
di antaranya perasaan malas belajar yang dibarengi dengan latar belakang pendidikan orang tua yang begitu rendah juga, anak juga kurang mendapa control orang tua dikarenakan anak-anak ini hasil dari broken home, terjadinya perceraian orang tua ataupun orang tua yang jauh mencari nafkah menjadi TKI atau TKW sehingga anak dititipkan kepada neneknya. Di samping itu pada saat terjadi wabah pandemic Covid-19 ini, persoalan pernikahan dini terus saja menjadi masalah, pemberlakukan social distancing rupanya bukan menjadi penghalang bagi kaum muda mudi ini untuk melangsungkan pernikahan, apa lagi sekolah diliburkan selama pandemic dan diganti dengan belajar daring, ini semakin menambah ruwetnya permasalahan pernikahan dini, karena justru dengan sekolah diliburkan belajar secara tatap muka, itu menimbulkan kebosanan pada anak-anak sehingga mereka malah lebih memilih menghabiskan waktu dengan berselancar di dunia maya, pacaran yang berakhir dengan menikah pada usia masih sekolah.

Banyak hal yang menyebabkan terjadinya pernikahan dini dikalangan anak muda, baik itu berasal dari faktor internalnya ataupun dari faktor eksternalnya. Faktor penyebab terjadinya pernikahan dini di desa Keruak antara lain adalah faktor kebudayaan, faktor pendidikan atau SDM yang rendah, faktor ekonomi keluarga, faktor agama, faktor kurangnya kontrol orangtua, murahnya biaya pernikahan, serta faktor lingkungan

\section{a. Faktor kebudayaan:}

Adanya tradisi "merariq" yaitu apabila seorang laki-laki ingin melakukan pernikahan maka perempuan yang mau diajak kawin harus dilarikan terlebih dahulu dan hal ini merupakan tindakan yang legal secara adat, sehingga pernikahan pada usia dini dilakukan dibawah tangan atau tidak tercatat dalam Negara (KUA). Biasanya pernikahan ini banyak terjadi ketika saat musim panen tiba, dan tidak menutup kemungkinan juga pada musim paceklik banyak yang melakukan perceraian, bahkan bisa dikatakan pernikahan dini kerap terjadi pada waktu libur panjang sekolah.

\section{b. Faktor pendidikan atau SDM yang rendah}

Faktor pendidikan sangat menentukan usia pernikahan, rata-rata masyarakat yang menikah usia dini adalah mereka yang tidak begitu perduli dengan pendidikan dan berasal dari keluarga yang berpendidikan rendah juga. Ada juga yang putus sekolah dan menikah disebabkan karena terjadinya hamil di luar nikah, ini yang menyebabkan perceraian terjadi dikarenakan ketidaksiapan kedua belah pihak dalam membina rumah tangga. Mirisnya lagi alasan menikah hanya karena tidak ingin mengerjakan banyak tugas dari sekolah dan berpikir bahwa sekolah itu tidak penting, yang terpenting adalah ia bisa mencari uang untuk hidup.

\section{c. Faktor ekonomi}

Faktor ekonomi merupakan salah satu penyebab terjadinya perceraian, pernikahan pada usia yang belum matang dan putus sekolah tentu akan berdampak pada kelangsungan hidup rumah tangga yang mereka bangun, pendidikan yang rendah dan tidak memiliki skill tentu ini akan menjadi bencana dalam kehidupan rumah tangga. Bagaimana tidak, pertengkaran dalam rumah tangga akan kerap terjadi jika perekonomian tidak terpenuhi, dibarengi dengan ego masing-masing yang masih labil menambah ruwetnya kehidupan yang mereka bangun, akibatnya banyak yang pada akhirnya memilih untuk menjadi TKI atau TKW untuk memenuhi perekonomian mereka. Ketika hal ini terjadi maka bencana baru akan datang, pasangan yang ditinggalkan akan mulai dengan banyak tuntutan mulai dari nafkah lahir dan nafkah batin yang tidak terpenuhi, terjadi perselingkuhan dengan dalih pasangan tidak mampu memenuhi kebutuhan hidup mereka walaupun sudah bekerja ke luar negeri sehingga salah satu 
pihak atau bahkan kedua belah pihak lebih memutuskan untuk bercerai.

\section{d. Faktor keluarga}

Tanpa kita sadari terkadang keluarga dapat memicu terjadinya perceraian, orangtua terlalu ikut campur dengan kehidupan rumah tangga anak dikarenakan orangtua menganggap anak-anak mereka belum cukup dewasa untuk menyelesaikan masalah mereka sendiri. Bahkan si anak juga terlalu banyak mengadu kepada orangtua ketika terjadi masalah dalam rumah tangga mereka. Hal ini terjadi karena pernikahn yang terjadi belum pada usia yang yang benar-benar matang sehingga walaupun sudah menikah anak kerap mencari perlindungan kepada orangtuanya, dan sebaliknya orangtua juga kerap ikut andil dalam masalah yang terjadi dalam rumah tangga anaknya. Ketika pertengkaran terjadi dalam rumah tangga anak maka yang memutuskan untuk melakukan perceraian itu justru datang dari orangtua.

\section{e. Faktor agama}

Pemahaman agama yang kurang menjadi penyebab dari terjadinya perceraian. Faktor agama yang mempermudah terjadinya perceraian cukup dengan menjatuhkan talak kepada sang istri walaupun tanpa melaporkan ke PPN atau KUA juga penyebab dari tingginya angka perceraian. Factor agama ini sangat sensitive sekali dalam pernikahan, suatu pernikahan membutuhkan pemahaman agama yang kuat untuk menjaga rumah tangga tetap utuh, tapi dalam kenyataan di lapangan, anak-anak yang menikah usia muda ini belum memiliki pemahamn agama yang kuat, terkadang ucapan mereka yang terdengar bercanda saja bisa menyebabkan jatuhnya talak kepada istri, perasaan emosional dan tanpa kontrol dari pasangan ini lah yang bisa menyebabkan jatuhnya talak yang berujung pada perceraian.

\section{f. Faktor biaya pernikahan}

Mudah dan murahnya biaya pernikahan juga memicu terjadinya kawin cerai dalam kalangan masyarakat desa Keruak, dengan biaya yang murah mereka dapat dengan mudah melakukan pernikahan, untuk biaya pernikahan di bawah tangan saja mereka hanya cukup membayar 50-100 ribu saja, sehingga itu yang membuat masyarakat tidak berpikir dengan panjang jika ingin melakukan perceraian, karena mereka berfikir jika mereka akan dengan mudah lagi untuk malakukan pernikahan.

\section{g. Faktor lingkungan}

Faktor lingkungan juga turut andil dalam menentukan tingginya angka pernikahan dini sekaligus angka perceraian. Masyarakat yang tinggal pada lingkungan yang rata-rata memiliki pendidikan rendah dan kebiasaan masyarakat untuk kawin cerai dapat memengaruhi kehidupan rumah tangga, apalagi dibarengi dengan pernikahan pada usia dini dimana tingkat kematangan emosi belum stabil.

\section{h. kurangnya control orang tua}

orang tua memegang peranan penting dalam tumbuh kembang anak, pentingnya control orang tua menjadi pondasi dasar untuk anak dalam menjalani hidup. Tapi dalam dewasa ini orang tua bahkan tidak bisa mengontrol pergaulan anak, ditambah lagi dengan adanya gadget yang walaupun anak terlihat diam di rumah, tapi orang tua tidak bisa mengontrol anaknya secara penuh tentang apa yang ia lakukan dengan gadget mereka. Terjadinya pergaulan bebas yang dikarenakan kurangnya control orang tua bahkan di awali dengan apa yang dilakukan anak di dunia maya dengan gadget mereka.

Pernikahan dini memiliki dampak yang cukup berbahaya bagi yang melakukannya baik pria ataupun bagi wanita, dan dalam berbagai aspek seperti kesehatan, psikologi, dan mental. Walaupun pernikahan usia dini ini memiliki dampak positif, namun dibandingkan dengan 
faktor negatifnya tentu sangat tidak seimbang. Ada berbagai alasan yang menyebabkan terjadinya pernikahan dini, terkadang tidak di sengaja atau yang sudah di rencanakan oleh orangtua maupun oleh anak itu sendiri. Adapun dampak dari pernikahan dini tersebut adalah sebagai berikut:

\section{Dampak positif}

a. Mengurangi beban orangtua, karena dengan menikahkan anaknya maka semua kebutuhan anaknya akan di penuhi oleh suami, dan bahkan orangtua berharap beban ekonominya juga akan dibantu.

b. Mencegah kemaksiatan, seperti terjadinya perzinahan atau kumpul kebo di kalangan remaja, dengan menikahkan anaknya orangtua akan merasa tenang, karena perzinahan atau bahkan hamil diluar nikah di kalangan remaja tidak akan terjadi.

\section{Dampak negatif}

a. Dampak terhadap pasangan suami istri

Terkadang anak yang menikah di usia dini tidak bisa memenuhi atau bahkan tidak tahu sebenarnya apa saja hak dan kewajibannya sebagai suami istri itu. Ketidaktahuan ini di sebabkan karena mental dan fisik yang belum matang dan belum benar-benar siap untuk menghadapi kehidupan setelah pernikahan, akibatnya masing-masing pihak ingin menang sendiri dan pertengkaran pun tidak dapat di hindari sehingga rentan terjadi perceraian.

\section{b. Dampak terhadap masing-masing} keluarganya

Pernikahan yang dilakukan anak-anak yang masih di bawah umur, mereka masih mempunyai sifat kekanak-kanakan dimana mereka belum bisa mandiri dalam mengurusi kehidupan keluarganya. Biasanya mereka yang melakukan pernikahan dini itu masih ikut dengan orangtua, masih tinggal dengan orangtuanya sehingga mereka tidak bisa mandiri dalam menyelesaikan permasalahan yang mereka hadapi. Ketika terjadi pertengkaran dalam rumah tangga mereka, maka orangtua masing-masing akan ikut campur dalam menyelesaikan masalah nya. Hal inilah yang akan mengurangi keharmonisan antar keluarga masing-masing, sehingga tak ayal jika justru orangtua jugalah yang meminta anak mereka untuk bercerai.

c. Dampak terhadap anak-anaknya

Tidaklah mudah untuk menjalankan pernikahan di usia muda, terutama bagi wanita yang melangsungkan pernikahan di bawah umur 17 tahun bahkan dibawah 16 tahun. Selain itu rentan perceraian di dalam pernikahan dini karena seringkali pertengkaran ataupun perselisihan itu berujung perceraian. Dan biasanya sebelum terjadi perceraian anak sudah lahir. Ketika orangtua bercerai lagi-lagi yang akan menjadi korban adalah si perempuan, sehingga ibu memiliki peran ganda untuk membesarkan anaknya dan mencari nafkah. Tak ayal banyak ibu-ibu muda atau janda muda pada akhirnya menjadi TKW untuk mencari nafkah, hingga kemudian anak itu di titipkan untuk sementara waktu ataupun selamanya kepada nenek dan kakeknya atau saudara ayah dan ibunya. Beberapa risiko juga mengancam anakanak yang nantinya lahir dari hubungan kedua orangtuanya yang menikah di bawah umur. Belum matangnya usia sang ibu, mendatangkan konsekuensi tertentu pada si calon anak. Misalnya, angka risiko kematian bayi lebih besar, bayi lahir dalam keadaan prematur, kurang gizi, dan anak berisiko terkena hambatan pertumbuhan atau stunting. Walaupaun kasus ini tidak ditemukan di lokasi penelitian tapi ini merupakan dampak pernikahan dini yang bisa mengintai siapa saja, dalam hal kasus kurang gizi pernah ditemukan di lokasi penelitian, hal ini diakibatkan oleh factor kemiskinan, ekonomi yang tidak memadai menyebabkan ibu kurang gizi selama proses kehamilan yang berakibat juga kepada janin yang dikandungnya.

\section{d. Putus sekolah}

Anak yang menikah pada saat masih duduk dibangku sekolah $100 \%$ dinyatakan akan meninggalkan bangku sekolah dengan alasan apapun. Sehingga pernikahan dini ini akan menambah angka putus sekolah dan menurunkan kwalitas pendidikan yang berakibat minimnya pengetahuan dan keterampilan, ini akan menyebabkan anak-anak ini tidak siap 
Jurnal Ilmiah Mandala Education

http://ejournal.mandalanursa.org/index.php/JIME/index

Terakreditasi Peringkat 4 (No. SK: 36/E/KPT/2019)

untuk menghadapi tantangan hidup yang semakin keras di era globalisasi ini dan berakibat memperpanjang ketimpangan sosial dimasyarakat.

e. Rentan mengalami depresi

Wanita yang menikah dini memiliki risiko lebih tinggi untuk mengalami kecemasan ataupun depresi ketika memiliki masalah dalam rumah tangganya karena belum bisa berpikir secara rasional dalam penyelesaian masalah rumah tangganya.

\section{f. Terjadi KDRT}

Perempuan yang menikah pada usia dini memiliki peluang lebih besar untuk mengalami kekerasan fisik, psikologis, emosional, dan isolasi sosial. Terjadinya KDRT ini juga turut nadil dalam meyumbnag angka perceraian di desa keruak, akan tetapi walaupun terjadi KDRT tidak pernah dilaporkan karena masih adanya perasaan sayang kepada pasangan yang walaupun pada ujungnya tetap saja terjadi pearceraian.

\section{g. Dampak di masyarakat}

Dampak pernikahan dini juga akan terjadi di masyarakat, diantaranya langgengnya garis kemiskinan. Hal itu terjadi karena pernikahan dini biasanya tidak dibarengi dengan tingginya tingkat pendidikan dan kemampuan finansial. Sehingga pasangan yang menikah pada usia dini tidak memiliki skill yang cukup untuk bekerja, dan mereka juga tidak memiliki pengetahuan yang luas untuk mendidik anak-anak mereka, sehingga hal itu juga akan berpengaruh besar terhadap cara didik orangtua yang belum matang secara usia dan tidak memiliki pengetahuan cukup kepada anak-anaknya. Pada akhirnya, berbuntut siklus kemiskinan yang berkelanjutan.

Dari hal di atas dapat disimpulkan bahwa dampak dari pernikahan dini lebih banyak memiliki dampak negatif dibanding dengan dampak positifnya. Bahkan dampak negatif perceraian adalah hal utama yang tidak bisa dihindari jika kedua belah pihak belum memiliki usia matang dalam mengambil keputusan terhadap suatu masalah.

Ironisnya perceraian yang terjadi di Desa Keruak seringkali terjadi pada anak-anak perempuan maupun anak laki-laki dari korban perceraian orangtuanya. Karena tak terurus dengan baik, anak laki-laki ataupun anak perempuan tadi mengambil jalan pintas dengan menikah walaupun usia mereka belum mencukupi. Pernikahan mereka lakukan dengan harapan jika mereka menikah ada yang mengurus, ada teman berbagi suka duka saat keluarga yang mereka harapkan untuk berlindung sudah tidak lengkap lagi. Ditambah lagi adanya anggapan yang beredar luas pada masyarakat desa Keruak Kabupaten Lombok Timur, jika seorang perempuan menikah usia di atas 20 tahun maka mereka dianggap perawan tua.

Proses "merariq" juga turut andil dalam pernikahn usia dini ini, dimana dalam proses merariq ini dengan melarikan seorang perempuan tanpa seizin orangtua mereka terlebih dahulu, biasanya jika perempuan sudah dibawa lari oleh laki-laki maka pantang bagi keluarga perempuan untuk mengambil kembali anaknya ataupun membatalkan pernikahan mereka, karena menurut kepercayaan yang beredar luas dalam masyarakat, jika pernikahan mereka dibatalkan maka si anak perempuan akan "mosot" atau menjadi perawan tua. Hal inilah yang ditakutkan oleh keluarga perempuan sehingga mau atau tidak mau, suka atau tidak suka mereka akan tetap menikahkan anaknya. Cara inilah yang biasa ditempuh oleh anak-anak usia dini yang sedang mabuk cinta agar pernikahan mereka direstui oleh keluarga kedua belah pihak.

Perasaan cinta dan keinginan untuk menyalurkan hasrat seksual yang tinggi juga memicu terjadinya pernikahan dini. Namun, menikah di bawah umur, apalagi hanya berdasar pada nafsu birahi ataupun keinginan lepas dari kesulitan ekonomi, pada akhirnya akan membuat banyak pasangan muda ini tidak bisa menyikapi masalah secara dewasa, sehingga perceraian menjadi satu-satunya jalan keluar dari masalah yang mereka hadapi, dan lagi-lagi anak anak menjadi korban dari perceraian orangtuanya. 
Jurnal Ilmiah Mandala Education

http://ejournal.mandalanursa.org/index.php/JIME/index

Terakreditasi Peringkat 4 (No. SK: 36/E/KPT/2019)

Kawin muda tampaknya menjadi salah satu penyebab terjadinya perceraian. Di desa Keruak Kabupaten Lombok Timur, Nusa Tenggara Barat ini sudah umum bagi lelaki maupun perempuan untuk menikah pertama kali di bawah usia 16 tahun. Biasanya perempuan yang berasal dari keluarga pra sejahtera, menikah untuk menyelesaikan masalah kesulitan ekonomi, dan akibat dari pernikahan tersebut tidak jarang mereka setelah dua atau tiga bulan akhirnya bercerai. Kasus seperti ini sering terjadi sehingga para petugas pun terkadang tidak mengetahui karena anak yang menikah di usia dini umumnya menikah di bawah tangan atau menikah siri, menikah sah secara agama tapi tidak tercatat dalam Negara.

Dari kasus pernikahan usia dini dan terjadinya kasus perceraian pada usia pernikahan yang masih seumur jagung di desa Keruak dikarenakan pada usia ini pola pikirnya belum matang, belum mengetahui dan menyadari tugas dan tanggungjawab, beban moril dan moral yang akan mreka emban, disamping itu ego yang masih labil sehingga belum mampu menyelesaikan masalah yang terjadi dalam rumah tangganya.

Untuk mengatasi tingginya angka perceraian usia muda di desa Keruak , hendaknya pemerintah daerah, seluruh staf desa Keruak PPN, KUA, Kepala Desa tokoh agama, tokoh masyarakat, dan para remaja dilibatkan dalam upaya memperbaiki perilaku kawin muda dan perceraian dini karena akan berdampak buruk pada dirinya sendiri, lingkungan dan tumbuh kembang anak.

Namun dari langkah-langkah tersebut tentu perlu dilakukan terus pengawasan, pembenahan, dan sosialisasi, meski permasalahan pernikahan usia muda dan perceraian dini tak semudah membalik telapak tangan. Tentunya apabila ada perhatian dari semua belah pihak maka tidak menutup kemungkinan masalah-masalah tersebut akan teratasi sehingga pernikahan usia dini dan perceraian dapat menurun atau teratasi. Sosialisasi terhadap dampak dari pernikahan dini dari BKKBN dan PKK Kabupaten harus kerap dilakukan dikalangan remaja agar mereka bisa lebih memahami akibat yang ditimbulkan jika melakukan pernikahan tanpa dibarengi dengan kesiapan mental. Perdes tentang pernikahan dini di desa Keruak juga belum ada sehingga masayarakt ataupun pemerintah setempat tidak bisa melarang jika ada yang ingin menikah, yang dilakukan oleh pemerintah pihak desa hanya memberikan waktu selama 7 hari kepada pasangan ini untuk berpikir, tetapi tidak ada yang pernah membatalkan pernikahan jika mereka sudah menginginkan hal itu, walaupun para alim ulama dan sesepuh desa sudah memberikan nasihat kepada pasangan ini.

Masyarakat yang menikah pada usia dini tentunya harus memikirkan dampak yang akan timbul jika mereka menikah, baik itu kesehatan, ekonomi atapun anak-anak mereka nantinya. Kebanyakan dari masyarakat tersebut masih kurang memahami arti dari sebuah pernikahan. Dan masyarakat atau pelaku perceraian belum memiliki pengetahuan dasar tetang makna sebuah keluarga atau keberadaan peran dan fungsi sebagai suami ataupun istri, serta belum mampu menyelesaikan masalah yang terjadi dalam rumah tangga disebabkan karena kematangan pola fikir dan emosional belum maksimal

\section{Simpulan dan Saran}

Simpulan

Dampak dari pernikahan dini berupa dampak positif dan dampak negatif, adapun dampak positifnya yaitu a) dapat mengurangi beban orangtua, karena dengan menikahkan anaknya maka semua kebutuhan anaknya akan di penuhi oleh suami. b) Mencegah kemaksiatan, seperti terjadinya perzinahan atau kumpul kebo di kalangan remaja. Sedangkan dampak negatif dari pernikahan dini antara lain a) anak yang menikah di usia dini tidak bisa memenuhi atau bahkan tidak tahu sebenarnya apa saja hak dan kewajibannya sebagai suami istri itu. b) Pernikahan yang dilakukan anak-anak yang masih di bawah umur, mereka masih mempunyai sifat kekanak-kanakan dimana mereka belum bisa mandiri dalam mengurusi 
kehidupan keluarganya. c). Anak menjadi terlantar akibat dari perceraian kedua orangtuanya. d) Belum matangnya usia sang ibu, mendatangkan konsekuensi tertentu pada si calon anak. e) Putus sekolah. f) Perempuan yang menikah pada usia dini memiliki peluang lebih besar untuk mengalami kekerasan fisik KDRT, psikologis, emosional, dan isolasi sosial. g) Langgengnya garis kemiskinan, hal itu terjadi karena pernikahan dini biasanya tidak dibarengi dengan tingginya tingkat pendidikan dan kemampuan finansial. Sehingga pasangan yang menikah pada usia dini tidak memiliki skill yang cukup untuk bekerja,

Dalam mengatasi tingginya angka perceraian usia muda di desa Keruak, hendaknya pemerintah daerah, seluruh staf Desa Keruak dan pihak-pihak yang terkait terutama masyarakat dan para remaja dilibatkan dalam upaya memperbaiki perilaku kawin muda dan perceraian dini karena akan berdampak buruk pada dirinya sendiri, lingkungan dan tumbuh kembang anak. Selain itu tentu perlu dilakukan terus pengawasan, pembenahan, dan sosialisasi, meski permasalahan pernikahan usia muda dan perceraian dini tak semudah membalik telapak tangan. Tentunya apabila ada perhatian dari semua belah pihak maka tidak menutup kemungkinan masalah-masalah tersebut akan teratasi sehingga pernikahan usia dini dan perceraian dapat menurun atau teratasi. Sosialisasi terhadap dampak dari pernikahan dini harus kerap dilakukan dikalangan remaja agar mereka bisa lebih memahami akibat yang ditimbulkan jika melakukan pernikahan tanpa dibarengi dengan kesiapan mental yang baik.

Saran

Untuk mengatasi masalah pernikahan dini yang bisa menyebabkan perceraian usia muda di Desa Keruak, hendaknya pemerintah daerah, seluruh staf desa Keruak PPN, KUA, Kepala Desa tokoh agama, tokoh masyarakat, masyarakat desa serta para remaja dilibatkan dalam upaya memperbaiki perilaku kawin muda dan perceraian dini karena akan berdampak buruk pada dirinya sendiri, lingkungan dan tumbuh kembang anak. Selain itu perlu dilakukan terus pengawasan, pembenahan, dan sosi alisasi, meski permasalahan pernikahan usia muda dan perceraian dini tak semudah membalik telapak tangan.

\section{DAFTAR PUSTAKA}

Aziz, Ridwan. 2011. Artikel :Perubahan Tingkah Laku Anak Akibat Perceraian. (Http:/ Bacaanonline.comperkawinanusia-muda-dan-pengaruhnya-terhadaptingkat-perceraian.

BkkbN, 2012.Kajian Pernikahan Dini Pada Beberapa Provinsi di Indonesia : Dampak Overpopulation, Akar Masalah dan Peran Kelembagaan di Daerah. Tersedia di http://www.bkkbn.go.id/pernikahandin ippt.

Good. J. Willian. 2004. Sosiologi Keluarga.Jakarta : Bumi Aksara

Hurlock, E. 2000.Psikologi Perkembangan. Edisi V. PT Gelora Aksara Pratama. Jakarta.

Kusmiran, E. 2012.Kesehatan Reproduksi Remaja dan Wanita. Salemba Medika. Jakarta.

Marlina, N. 2012.Hubungan Antara Tingkat Pendidikan Orang Tua dan Kematangan Emosi dengan Kecendrungan Menikah Dini.Tersedia di

http://repository.uad.ac.id/ipi123305.c om.

Miles \& Huberman. (1992). Analisis Data Kualitatif. (terjemahan). Jakarta: Universitas Indonesia (UI Press).

Moleong, Lexy, J. 2007. Metode Penelitian Kualitatif. Bandung : PT Remaja Rosdakarya

Nana Syaodih Sukmadinata .(2009). Metode penelitian pendidikan. Bandung: Remaja Rosdakarya.

Sarwono, S.W. 2011. Psikologi Remaja. Edisi revisi.PT Raja Grafindo Persada. Jakarta. 
Jurnal Ilmiah Mandala Education

http://ejournal.mandalanursa.org/index.php/JIME/index

Vol. 6. No. 2. Oktober 2020

Terakreditasi Peringkat 4 (No. SK: 36/E/KPT/2019)

Soejono Soekanto. 1990. Sosiologi Keluarga.

Jakarta: Rineka Cipta

Undang-undang Perkawinan No.1 Tahun 1974

Undang-undang RI No. tahun 2019 Tentang

perubahan atas UU No 1 tahun 1974 